\title{
Influence of the Arene Ligand, the Number and Type of Metal Centers, and the Leaving Group on the in Vitro Antitumor Activity of Polynuclear Organometallic Compounds
}

\author{
Maria G. Mendoza-Ferri, ${ }^{\dagger}$ Christian G. Hartinger, $,{ }^{\dagger}, \dot{\dagger}$ Alexey A. Nazarov, ${ }^{*}, \dagger$ \\ Rene E. Eichinger ${ }^{\dagger}$ Michael A. Jakupec, ${ }^{\dagger}$ Kay Severin, ${ }^{*}$ and Bernhard K. Keppler ${ }^{\dagger}$ \\ ${ }^{\dagger}$ Institute of Inorganic Chemistry, University of Vienna, Währinger Strasse 42, A-1090 Vienna, Austria, and \\ *Institut des Sciences et Ingénierie Chimiques, Ecole Polytechnique Fédérale de Lausanne (EPFL), CH-1015 \\ Lausanne, Switzerland
}

Received August 13, 2009

\begin{abstract}
Dinuclear ruthenium complexes were shown to exhibit strong antiproliferative properties in human tumor cell lines. In order to extend the structure-activity relationships (SARs), a series of new $\mathrm{Ru}^{\text {II }}$ (arene) $\mathrm{X}$ complexes ( $\mathrm{X}=\mathrm{Cl}, \mathrm{Br}, \mathrm{I}$ ) linked by pyridinone-based spacers were synthesized and assayed for their in vitro antineoplastic effect. The SARs were established in terms of the arene ligand, the leaving group (the halide ligand), and the nature and number of the metal centers. It was demonstrated that, besides the previously shown effect of the spacer length, the nature of the metal center has the biggest influence on the in vitro anticancer activity. The halide ligand had no effect on the cytotoxicity, due to rapid formation of the same aquation product for all evaluated compounds. Furthermore, nearly identical activity was observed when varying the arene ligand from $p$-cymene to biphenyl. However, the number of metal centers was found to be important, with the dinuclear compound being more active than the analogous mono- and trinuclear species.
\end{abstract}

\section{Introduction}

Organometallic complexes have recently gained attention as antitumor agents ${ }^{1-5}$ and can be tuned to facilitate the uptake of the complexes into the cells or for selectivity for reactions with DNA or proteins. ${ }^{6,7}$ In order to enable covalent interaction with biological targets, the compounds are usually equipped with a halide leaving group, most frequently a chloride. ${ }^{2,3,6,8-11}$ Replacement of chloride by other halides or carboxylates may play a role in the behavior

*To whom correspondence should be addressed. Phone: +43-1-427752609. Fax: +43-1-4277-9526. E-mail: christian.hartinger@univie.ac.at; alex.nazarov@univie.ac.at.

(1) Allardyce, C. S.; Dorcier, A.; Scolaro, C.; Dyson, P. J. Appl. Organomet. Chem. 2005, 19, 1-10.

(2) Yan, Y. K.; Melchart, M.; Habtemariam, A.; Sadler, P. J. Chem. Commun. 2005, 4764-4776.

(3) Liu, H.-K.; Berners-Price, S. J.; Wang, F.; Parkinson, J. A.; Xu, J.; Bella, J.; Sadler, P. J. Angew. Chem., Int. Ed. 2006, 45, 8153-8156.

(4) Hartinger, C. G.; Nazarov, A. A.; Ashraf, S. M.; Dyson, P. J.; Keppler, B. K. Curr. Med. Chem. 2008, 15, 2574-2591.

(5) Hartinger, C. G.; Dyson, P. J. Chem. Soc. Rev. 2009, 38, 391-401.

(6) Scolaro, C.; Chaplin, A. B.; Hartinger, C. G.; Bergamo, A.; Cocchietto, M.; Keppler, B. K.; Sava, G.; Dyson, P. J. Dalton Trans. 2007, 5065-5072.

(7) Dorcier, A.; Hartinger, C. G.; Scopelliti, R.; Fish, R. H.; Keppler, B. K.; Dyson, P. J. J. Inorg. Biochem. 2008, 102, 1066-1076.

(8) Chen, H.; Parkinson, J. A.; Morris, R. E.; Sadler, P. J. J. Am. Chem. Soc. 2003, 125, 173-186.

(9) Fernandez, R.; Melchart, M.; Habtemariam, A.; Parsons, S.; Sadler, P. J. Chem.-Eur. J. 2004, 10, 5173-5179.

(10) Scolaro, C.; Bergamo, A.; Brescacin, L.; Delfino, R.; Cocchietto, M.; Laurenczy, G.; Geldbach, T. J.; Sava, G.; Dyson, P. J. J. Med. Chem. $\mathbf{2 0 0 5}, 48,4161-4171$.

(11) Scolaro, C.; Geldbach, T. J.; Rochat, S.; Dorcier, A.; Gossens, C.; Bergamo, A.; Cocchietto, M.; Tavernelli, I.; Sava, G.; Rothlisberger, U.; Dyson, P. J. Organometallics 2006, 25, 756-765. of such complexes in aqueous solution. ${ }^{12}$ Furthermore, in dependence of the electronic properties of the ligands, the complexes' properties may be modulated in terms of their aquation, $\mathrm{p} K_{\mathrm{a}}$ of the aqua complexes, and nucleobase specificity (e.g., in $\left[\mathrm{Ru}\left(\eta^{6}\right.\right.$-arene) $\mathrm{Cl}($ ethylenediamine $\left.)\right] \mathrm{PF}_{6},{ }^{8,9}$ RAPTA, and analogous complexes ${ }^{6,10,11,13}$ ). Furthermore, (organometallic) analogues with Os and $\mathrm{Rh}$ were assayed for their tumor-inhibiting properties. ${ }^{14-19}$

Ruthenium complexes have shown potential as anticancer agents with high activity in different tumor models. As a result of tumor selectivity, ${ }^{20}$ they show low general toxicity,

(12) Ang, W. H.; Daldini, E.; Scolaro, C.; Scopelliti, R.; JuilleratJeannerat, L.; Dyson, P. J. Inorg. Chem. 2006, 45, 9006-9013.

(13) Berger, I.; Hanif, M.; Nazarov, A. A.; Hartinger, C. G.; John, R.; Kuznetsov, M. L.; Groessl, M.; Schmitt, F.; Zava, O.; Biba, F.; Arion, V. B.; Galanski, M.; Jakupec, M. A.; Juillerat-Jeanneret, L.; Dyson, P. J.; Keppler, B. K. Chem.-Eur. J. 2008, 14, 9046-9057.

(14) Dorcier, A.; Dyson, P. J.; Gossens, C.; Rothlisberger, U.; Scopelliti, R.; Tavernelli, I. Organometallics 2005, 24, 2114-2123.

(15) Dorcier, A.; Ang, W. H.; Bolano, S.; Gonsalvi, L.; JuilleratJeannerat, L.; Laurenczy, G.; Peruzzini, M.; Phillips, A. D.; Zanobini, F.; Dyson, P. J. Organometallics 2006, 25, 4090-4096.

(16) Peacock, A. F. A.; Habtemariam, A.; Fernandez, R.; Walland, V.; Fabbiani, F. P. A.; Parsons, S.; Aird, R. E.; Jodrell, D. I.; Sadler, P. J. J. Am. Chem. Soc. 2006, 128, 1739-1748.

(17) Cebrian-Losantos, B.; Krokhin, A. A.; Stepanenko, I. N.; Eichinger, R.; Jakupec, M. A.; Arion, V. B.; Keppler, B. K. Inorg. Chem. 2007, 46, 5023-5033.

(18) Peacock, A. F. A.; Melchart, M.; Deeth, R. J.; Habtemariam, A.; Parsons, S.; Sadler, P. J. Chem.-Eur. J. 2007, 13, 2601-2613. Kandioller, W.; Hartinger, C. G.; Nazarov, A. A.; Kuznetsov, M. L.; John, R.; Bartel, C.; Jakupec, M. A.; Arion, V. B.; Keppler, B. K. Organometallics 2009, 28, $4249-4251$.

(19) Peacock, A. F. A.; Sadler, P. J. Chem. Asian J. 2008, 3, 18901899.

(20) Timerbaev, A. R.; Hartinger, C. G.; Aleksenko, S. S.; Keppler, B. K. Chem. Rev. 2006, 106, 2224-2248. 


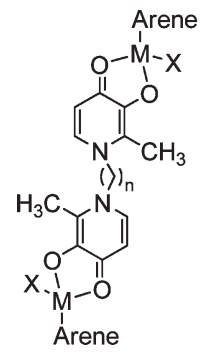

1a $\mathrm{M}=\mathrm{Os}, \mathrm{n}=6$, arene $=p$-cymene, $\mathrm{X}=\mathrm{Cl}$

1b $\mathrm{M}=\mathrm{Ru}, \mathrm{n}=6$, arene $=p$-cymene, $\mathrm{X}=\mathrm{C}$

2a $\mathrm{M}=\mathrm{Os}, \mathrm{n}=8$, arene $=p$-cymene, $\mathrm{X}=\mathrm{Cl}$

2b $\mathrm{M}=\mathrm{Ru}, \mathrm{n}=8$, arene $=p$-cymene, $\mathrm{X}=\mathrm{Cl}$

3a $\mathrm{M}=\mathrm{Ru}, \mathrm{n}=6$, arene $=p$-cymene, $\mathrm{X}=\mathrm{Br}$

3b $\mathrm{M}=\mathrm{Ru}, \mathrm{n}=6$, arene $=p$-cymene, $\mathrm{X}=1$

$4 \mathrm{M}=\mathrm{Ru}, \mathrm{n}=6$, arene $=$ biphenyl, $X=\mathrm{Cl}$
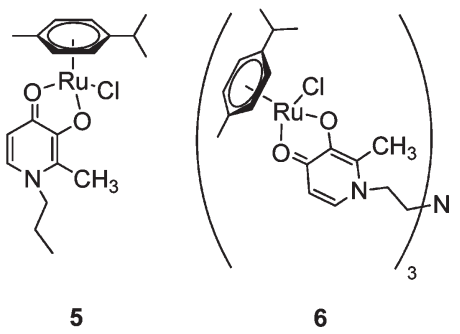

Figure 1. Chemical formulas of the synthesized mono- and polynuclear ruthenium(II) - and osmium(II)-arene complexes.

and two $\mathrm{Ru}(\mathrm{III})$ compounds have reached the stage of clinical evaluation. ${ }^{21,22}$

Polynuclear organometallic $\mathrm{Ru}$ compounds have been rarely studied for their anticancer properties, and if they were assayed, they exhibited lower activity than their mononuclear analogues, ${ }^{23,24}$ whereas in the case of platinum complexes the linkage of metal centers has led to the development of compounds overcoming resistance of cancer cells to cisplatin. ${ }^{25-27}$ We have recently reported on the development of dinuclear organometallic compounds ${ }^{28,29}$ with high in vitro anticancer activity, whereas the mononuclear maltolato compound was found to be inactive. ${ }^{18}$ The activity of compounds initially appeared to be determined by their lipophilicity; ${ }^{28}$ however, DNA and protein interaction studies revealed high potential for DNA- protein and interduplex cross-linking. ${ }^{30}$

In order to set up structure-activity relationships for ruthenium(II)-arene complexes with pyridinonato ligands, the influence of the type of metal center and of the leaving halide ligand as well as of the nature of the arene group and the number of metal centers on the antineoplastic activity was studied.

\section{Results and Discussion}

Dinuclear Ru(II)-arene complexes with the metal centers being linked by coordination to alkyl-bridged pyridinone ligands were shown to exhibit high in vitro antitumor activity, and studies on their mode of action were reported previously. ${ }^{28-30}$ In order to expand the structure-activity relationships from the mere spacer length to other structural

(21) Rademaker-Lakhai, J. M.; Van Den Bongard, D.; Pluim, D.; Beijnen, J. H.; Schellens, J. H. M. Clin. Cancer Res. 2004, 10, 3717-3727.

(22) Hartinger, C. G.; Zorbas-Seifried, S.; Jakupec, M. A.; Kynast, B.; Zorbas, H.; Keppler, B. K. J. Inorg. Biochem. 2006, 100, 891-904.

(23) Huxham, L. A.; Cheu, E. L. S.; Patrick, B. O.; James, B. R. Inorg. Chim. Acta 2003, 352, 238-246.

(24) Chen, H.; Parkinson, J. A.; Novakova, O.; Bella, J.; Wang, F.; Dawson, A.; Gould, R.; Parsons, S.; Brabec, V.; Sadler, P. J. Proc. Natl. Acad. Sci. U.S.A. 2003, 100, 14623-14628.

(25) Farrell, N.; Qu, Y.; Bierbach, U.; Valsecchi, M.; Menta, E. Structure-activity relationships within di- and trinuclear platinum phase-I clinical anticancer agents. Cisplatin: Chemistry and Biochemistry of a Leading Anticancer Drug; Lippert, B., Ed.; Wiley-VCH, Helvetica Chimica Acta: Weinheim, Zurich, 1999; pp 479-496.

(26) Farrell, N. Polynuclear platinum drugs. In Metal Ions in Biological Systems; Sigel, A.; Sigel, H., Eds.; Marcel Dekker: New York, 2004; Vol. 42, pp 251-296.

(27) Kloster, M.; Kostrhunova, H.; Zaludova, R.; Malina, J.; Kasparkova, J.; Brabec, V.; Farrell, N. Biochemistry 2004, 43, 7776-7786.

(28) Mendoza-Ferri, M. G.; Hartinger, C. G.; Eichinger, R. E.; Stolyarova, N.; Jakupec, M. A.; Nazarov, A. A.; Severin, K.; Keppler, B. K. Organometallics 2008, 27, 2405-2407.

(29) Mendoza-Ferri, M. G.; Hartinger, C. G.; Nazarov, A. A.; Kandioller, W.; Severin, K.; Keppler, B. K. Appl. Organomet. Chem. 2008, 22, 326-332.

(30) Nováková, O.; Nazarov, A. A.; Hartinger, C. G.; Keppler, B. K.; Brabec, V. Biochem. Pharmacol. 2009, 77, 364-374. features, herein the series of dinuclear complexes is extended to trinuclear compounds, the ruthenium center has been replaced by Os(II), and the influence of the arene ligand and the leaving halide is discussed (Figure 1). The new compounds were obtained by a synthetic route similar to that described recently. ${ }^{28,29}$ For the synthesis of the iodido and bromido complexes the dimeric precursor $\left[\left(\eta^{6}-p\right.\right.$-cymene) $\left.\mathrm{RuCl}_{2}\right]_{2}{ }^{31}$ was converted into $\left[\left(\eta^{6}-p \text {-cymene }\right) \mathrm{RuBr}_{2}\right]_{2}$ and $\left[\left(\eta^{6}-p \text {-cymene }\right) \mathrm{RuI}_{2}\right]_{2}$ by treatment with $\mathrm{KBr}$ and $\mathrm{KI}$, respectively. The new compounds were obtained in good to moderate yields and were characterized by elemental analysis, NMR spectroscopy, and ESI-MS.

Influence of the Metal Center: Ruthenium vs Osmium. In comparison to numerous $\mathrm{Ru}(\mathrm{II})$-arene complexes, which were already evaluated for their tumor-inhibiting properties, only a few Os(II)-arene complexes with anticancer activity were reported. Recently, Dyson et al. have compared the effect of replacing Ru by Os in RAPTA-C, a well-explored drug candidate, and found for Ru and Os only minor differences in terms of in vitro anticancer activity, while a structurally related $\mathrm{Rh}$ complex was significantly more active. ${ }^{15}$ A comparison of $\mathrm{Os}$ and $\mathrm{Ru}$ ethylenediamine complexes revealed that the $\mathrm{Ru}$ compounds are much more active than their Os analogues, ${ }^{16}$ whereas in other cases the Os compounds are the more potent agents, ${ }^{32}$ or both compounds are equally active as in the case with paullone ligands. ${ }^{33}$

When the osmium(II) complexes $\mathbf{1 a}$ and $\mathbf{2} \mathbf{a}$ are compared to the analogous $\mathrm{Ru}(\mathrm{II})$ complexes $\mathbf{1 b}$ and $\mathbf{2} \mathbf{b}$, a first obvious difference between the $\mathrm{Ru}$ and Os complexes is a significantly lower solubility in water of both osmium complexes. Comparison of the aquation by ${ }^{1} \mathrm{H} \mathrm{NMR}$ and UV-vis spectroscopy revealed similarly rapid exchange of the halogenido by aqua ligands for both $\mathrm{Os}$ and $\mathrm{Ru}$ complexes. Accordingly, the ${ }^{1} \mathrm{H}$ NMR spectra of the osmium complexes in $\mathrm{D}_{2} \mathrm{O}$ did not change over time (followed for $24 \mathrm{~h}$ ) or after addition of $\mathrm{AgNO}_{3}$ to induce the release of the chlorido ligands, also suggesting instant and quantitative aquation. A kinetic study on the stability of $\mathbf{1 a}$ in water by UV-vis spectroscopy (two absorption bands at 322 and $222 \mathrm{~nm}$ ) indicated only slight changes within $24 \mathrm{~h}$.

Investigations on the in vitro activity of the osmium complexes 1a and $\mathbf{2 a}$ in the human tumor cell line SW480 have shown a SAR parallel to the analogous ruthenium complexes: ${ }^{28}$ a correlation between the chain length and the cytotoxicity was observed, but the Os complexes are approximately 3-6 times less active than the Ru analogues $\mathbf{1 b}$ and $\mathbf{2 b}$ (Table 1). The influence of the metal center was

(31) Bennett, M. A.; Huang, T. N.; Matheson, T. W.; Smith, A. K. Inorg. Synth. 1982, 21, 74-78.

(32) Peacock, A. F. A.; Parsons, S.; Sadler, P. J. J. Am. Chem. Soc. 2007, 129, 3348-3357.

(33) Schmid, W. F.; John, R. O.; Arion, V. B.; Jakupec, M. A.; Keppler, B. K. Organometallics 2007, 26, 6643-6652. 
Table 1. Water Solubility and $\mathrm{IC}_{50}$ Values of $\mathrm{Ru}(\mathrm{II})$-Arene Complexes in Human SW480 and A2780 Cells

\begin{tabular}{lccc}
\hline & & \multicolumn{2}{c}{$\mathrm{IC}_{50} / \mu \mathrm{M}$} \\
\cline { 3 - 4 } compound & solubility $/ \mathrm{mM}$ & $\mathrm{SW} 480$ & $\mathrm{~A} 2780$ \\
\hline $\mathbf{1 a}$ & 1.6 & $88 \pm 4$ & \\
$\mathbf{1} \mathbf{b}^{a}$ & 3.9 & $26 \pm 8$ & $30 \pm 6$ \\
$\mathbf{2 a}$ & 0.2 & $15 \pm 5$ & $29 \pm 13$ \\
$\mathbf{2 b}$ & 2.2 & $2.5 \pm 0.2$ & $5.7 \pm 0.5$ \\
$\mathbf{3 a}$ & 0.6 & $54 \pm 4$ & $52 \pm 15$ \\
$\mathbf{3 b}$ & 0.1 & $33 \pm 4$ & $36 \pm 2$ \\
$\mathbf{4}$ & 0.6 & $25.7 \pm 0.3$ & $43 \pm 1$ \\
$\mathbf{5}$ & 10.3 & $42 \pm 1$ & $88 \pm 12$ \\
$\mathbf{6}$ & 7.4 & $59 \pm 18$ & $80 \pm 7$ \\
$\mathbf{7}^{b}$ & $>25$ & $>100$ & $>100$ \\
\multicolumn{2}{c}{${ }^{a}$ From ref 28. ${ }^{b}$ From ref 18.} & &
\end{tabular}

confirmed in a separate panel of human tumor cell lines (LCLC-103H, A-427, RT-4, MCF-7, DAN-G, 5637). 1a exhibited $\mathrm{IC}_{50}$ values $>20 \mu \mathrm{M}$ in all cell lines, whereas $\mathbf{1 b}$ has $\mathrm{IC}_{50}$ values $<20 \mu \mathrm{M}$ in A-427 and MCF-7 cells. ${ }^{34}$

The higher activity of the compounds with longer spacers may be explained by the higher lipophilicity, as indicated by the lower water solubility, ${ }^{28,34}$ but also by different extents of interaction with DNA and proteins. ${ }^{30}$ The Os complexes are significantly more lipophilic than the Ru compounds, and therefore it is assumed that the generally more inert nature of third-row transition metal ions might play an important role for antineoplastic efficacy. Since hydroxido complexes do not react as readily as aqua complexes with biomolecules, the increased propensity of Os complexes to form hydroxido species at physiological $\mathrm{pH}$ might lower the reactivity toward biological targets and alter the cellular uptake. ${ }^{18}$

Influence of the Halide: Chloride vs Bromide vs Iodide. In an attempt to alter the aquation kinetics and thereby the anticancer activity of dinuclear $\mathrm{Ru}(\mathrm{II})$-arene complexes, the bromido and iodido compounds $\mathbf{3} \mathbf{a}$ and $\mathbf{3 b}$ were prepared and compared to their chlorido analogue $\mathbf{1 b}$. The kinetic studies on the stability of the bromido and iodido complexes $\mathbf{3 a}$ and $\mathbf{3 b}$, respectively, in water by $\mathrm{UV}-$ vis spectroscopy have shown no spectral changes over $24 \mathrm{~h}$. This is similar to the behavior of $\mathbf{1 b}$, since aquation of the ruthenium complexes was observed within minutes. ${ }^{34}$ Comparing the ${ }^{1} \mathrm{H}$ NMR spectra of the chlorido complex $\mathbf{1 b}$ and the bromido complex 3a in $\mathrm{CDCl}_{3}$ (Figure 2) shows for $\mathbf{1 b}$ four doublets for the protons of the $p$-cymene rings, indicating that the epimerization of the chiral metal center, leading to nonequivalent aromatic protons, is sufficiently slow to be observed, whereas the spectrum of $\mathbf{3 a}$ contained only two doublets. In addition, the chemical shift of the aromatic protons is slightly different. Mixing both $\mathrm{CDCl}_{3}$ solutions and addition of a small amount of $\mathrm{D}_{2} \mathrm{O}$ induced a change in the multiplicity of the aromatic proton signals. This suggests that the fast aquation results in the formation of a single product that is identical for both compounds, i.e., $\{[\mathrm{Ru}(p$ cymene $\left.\left.)\left(\mathrm{H}_{2} \mathrm{O}\right)\right]_{2} \mathrm{~L}\right\}^{+2}$, which was also confirmed by $\mathrm{UV}$-vis spectroscopy, with both aquation products showing the same absorption maximum. A cytotoxicity assay involving the halide complexes revealed mostly small differences of the in vitro activity of $\mathbf{1 b}, \mathbf{3 a}$, and $\mathbf{3 b}$ in SW480 and A2780 cells

(34) Mendoza-Ferri, M. G.; Hartinger, C. G.; Mendoza, M. A.; Groessl, M.; Egger, A. E.; Eichinger, R. E.; Mangrum, J. B.; Farrell, N. P.; Maruszak, M.; Bednarski, P. J.; Klein, F.; Jakupec, M. A.; Nazarov, A. A.; Severin, K.; Keppler, B. K. J. Med. Chem. 2009, 52, 916-925.

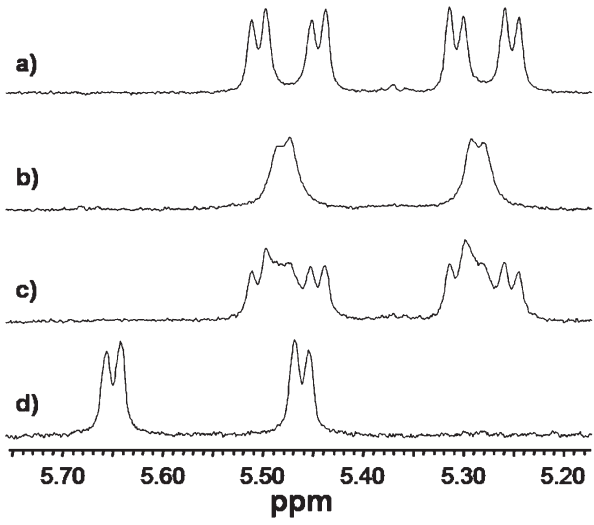

Figure 2. ${ }^{1} \mathrm{H}$ NMR spectra of (a) $\mathbf{1 b}$ in $\mathrm{CDCl}_{3}$, (b) $\mathbf{3}$ a in $\mathrm{CDCl}_{3}$, (c) $\mathbf{1 b}$ and $\mathbf{3 a}$ in $\mathrm{CDCl}_{3}$, and (d) $\mathbf{1 b}$ and $\mathbf{3 a}$ in $\mathrm{D}_{2} \mathrm{O}$.

(see Table 1). This is likely the effect of rapid aquation, which leads to the formation of the same products.

Influence of the Arene Group: p-Cymene vs Biphenyl. The arene ligand is another structural feature that was found to play an important role in the mode of action and the tumor-growth inhibition of $\mathrm{Ru}(\mathrm{II})$ complexes. ${ }^{35,36}$ In order to extend the $\pi$-electron ring system of the arene ligand and to enable hydrophobic $\pi-\pi$ stacking interactions with DNA bases, the $p$-cymene of ligand of $\mathbf{1 b}$ was replaced by biphenyl, leading to the more lipophilic complex 4. Compound $\mathbf{4}$ is ca. 6 times less soluble than $\mathbf{1 b}$, but surprisingly exhibits a similar biological activity (see Table 1). This result is another indication that the lipophilicity does not exclusively determine the antitumor activity of the compound class. For clarification of SARs, a larger set of compounds might be required. ${ }^{10,11,35,36}$ However, for the biphe$\mathrm{nyl} / p$-cymene system in $[\mathrm{Ru}(\text { arene })(\mathrm{en}) \mathrm{Cl}]^{+}$complexes similar ratios of $\mathrm{IC}_{50}$ values were reported. ${ }^{35,36}$

Influence of the Number of Ruthenium Centers: Mono- vs Di- vs Trinuclear. The in vitro anticancer activity of $\mathbf{1 b}$, its closest mononuclear analogue 5, and the trinuclear complex $\mathbf{6}$ (Figure 1) was compared. In both SW480 and A2780 cells, 1b was identified as the most active species, while there is no meaningful difference between the mono- and the trinuclear complex (see Table 1). Comparing the lipophilicity of the three compounds, reflected by their solubility in water, shows that the mononuclear complex $\mathbf{5}$ is the most soluble, followed by 6 and $\mathbf{1 b}$ (Table 1). The good solubility of $\mathbf{6}$ is surprising and might be explained by the presence of a protonable tertiary amine. The dinuclear compound $\mathbf{1 b}$ represents a good compromise between solubility and lipophilicity necessary for cellular uptake. The modification of the compound to link a higher number of ruthenium moieties improved the water solubility but decreased the biological effect.

Furthermore, the comparison of the mononuclear pyridinonato compound $\mathbf{5}$ with the maltolato analogue chlorido(maltolato- $\kappa O 4)\left(\eta^{6}-p\right.$-cymene)ruthenium(II), $7,{ }^{18}$ reveals a drastically higher in vitro activity for 5 (Table 1).

\section{Conclusions}

The influence of modifying the structure of dinuclear $\mathrm{Ru}-$ (II)-arene complexes linked by chelating pyridinone-based

(35) Morris, R. E.; Aird, R. E.; Murdoch, P. d. S.; Chen, H.; Cummings, J.; Hughes, N. D.; Parsons, S.; Parkin, A.; Boyd, G.; Jodrell, D. I.; Sadler, P. J. J. Med. Chem. 2001, 44, 3616-3621.

(36) Chen, H.; Parkinson, J. A.; Parsons, S.; Coxall, R. A.; Gould, R. O.; Sadler, P. J. J. Am. Chem. Soc. 2002, 124, 3064-3082. 
spacers was investigated with regard to tumor-inhibiting activity in vitro. Taking water solubility as a measure for lipophilicity, an increase of the latter by extending the spacer length results in a higher antineoplastic potency in both Os and $\mathrm{Ru}$ compounds. Changing the nuclearity causes a less pronounced effect on in vitro activity than changing the metal center from $\mathrm{Ru}$ to $\mathrm{Os}$ or modifying the spacer length. Although the trinuclear complex is more water-soluble than the mononuclear compound, both were found to exhibit similar antitumor activity. Modifying the leaving group or changing the arene ligand to a more extended $\pi$-electron system has only minor effects on the in vitro activity. Notably, replacing the cymene by a biphenyl group causes a significant change in lipophilicity but does not alter the activity against cancer cells to a meaningful extent. This shows that factors other than lipophilicity relevant for the capability of hitting biomolecular targets, as observed for other non-platinum as well as for platinum compounds, ${ }^{6,20,37-41}$ might play an important role in the mode of action.

\section{Experimental Section}

All the chemicals purchased were used without further purifications. All reactions were carried out in dry solvents and under argon atmosphere. Bis[dichlorido $\left(\eta^{6}\right.$-biphenyl)ruthenium(II)], ${ }^{42}$ bis[dichlorido $\left(\eta^{6}\right.$-p-cymene)ruthenium(II)], 31 3-benzyloxy-2methyl-4-pyrone, 1,6-bis[3-hydroxy-2-ethyl-4(1H)-pyridinon-1yl]hexane and 1,8-bis[3-hydroxy-2-ethyl-4(1H)-pyridinon-1yl]octane, ${ }^{43}$ bis[dichlorido $\left(\eta^{6}-p\right.$-cymene $)$ osmium(II) $),{ }^{44}$ and chlorido[2-methyl-3-(oxo- $\kappa O)$-1-propyl-4(1H)-pyridinonato- $\kappa O 4]$ $\left(\eta^{6}\right.$-p-cymene)ruthenium(II) $(\mathbf{5})^{45}$ were prepared according to literature procedures. The dimeric precursor bis[dichlorido $\left(\eta^{6}-p\right.$ cymene)ruthenium(II)] was converted into bis[dibromido $\left(\eta^{6}-p\right.$ cymene)ruthenium(II)] and bis[diiodido $\left(\eta^{6}-p\right.$-cymene)ruthenium(II)]. ${ }^{46}$ Silica gel (Fluka-60, 70-230 mesh) and silica gel plates (Polygram SIL G/UV254) were used for preparative and thinlayer chromatography, respectively.

Melting points were determined with a Büchi B-540 apparatus and are uncorrected. Elemental analyses were carried out with a Perkin-Elmer $2400 \mathrm{CHN}$ elemental analyzer at the Microanalytical Laboratory of the University of Vienna. NMR spectra were recorded on a Bruker Avance DPX400 spectrometer (Ultrashield Magnet) at $400.13\left({ }^{1} \mathrm{H}\right)$ and $100.63 \mathrm{MHz}$ $\left({ }^{13} \mathrm{C}\left\{{ }^{1} \mathrm{H}\right\}\right)$ at $25^{\circ} \mathrm{C}$ in $d_{4}-\mathrm{MeOH}$ or in $d_{6}$-DMSO. Electrospray ionization (ESI) mass spectra were recorded on a Bruker Esquire3000 instrument (Bruker Daltonics, Bremen, Germany). Theoretical and experimental isotope distributions were compared. Ultraviolet-visible (UV-vis) spectra were recorded on a Perkin-Elmer Lambda 650 instrument from 500 to $200 \mathrm{~nm}$.

(37) Reedijk, J. Chem. Rev. 1999, 99, 2499-2510

(38) Sulyok, M.; Hann, S.; Hartinger, C. G.; Keppler, B. K.; Stingeder, G.; Koellensperger, G. J. Anal. At. Spectrom. 2005, 20, 856-863.

(39) Groessl, M.; Reisner, E.; Hartinger, C. G.; Eichinger, R.; Semenova, O.; Timerbaev, A. R.; Jakupec, M. A.; Arion, V. B.; Keppler, B. K. J. Med. Chem. 2007, 50, 2185-2193.

(40) Hartinger, C. G.; Ang, W. H.; Casini, A.; Messori, L.; Keppler, B. K.; Dyson, P. J. J. Anal. At. Spectrom. 2007, 22, 960-967.

(41) Casini, A.; Hartinger, C. G.; Gabbiani, C.; Mini, E.; Dyson, P. J.; Keppler, B. K.; Messori, L. J. Inorg. Biochem. 2008, 102, 564-575.

(42) Morris, R. E.; Sadler, P. J.; Chen, H.; Jodrell, D. Half-sandwich ruthenium(II) compounds comprising nitrogen containing ligands for treatment of cancer. 2000-GB4144, 2001.

(43) Harris, R. L. N. Aust. J. Chem. 1976, 29, 1329-1334.

(44) Kiel, W. A.; Ball, R. G.; Graham, W. A. G. J. Organomet. Chem. 1990, 383, 481-496.

(45) Lang, R.; Polborn, K.; Severin, T.; Severin, K. Inorg. Chim. Acta $1999,294,62-67$.

(46) da Silva, A. C.; Piotrowski, H.; Mayer, P.; Polborn, K.; Severin, K. Dalton 2000, 2960-2963.
Purity of $>95 \%$ for all compounds was confirmed via elemental analysis (see Supporting Information).

Syntheses. Bis[dibromido $\left(\eta^{6}-p\right.$-cymene $)$ ruthenium(II)], $\mathbf{1}^{\prime}$. A solution of potassium bromide $(3.00 \mathrm{~g}, 25 \mathrm{mmol})$ in water $(20 \mathrm{~mL})$ was added to a solution of bis[dichlorido $\left(\eta^{6}-p\right.$-isopropyltoluol)ruthenium(II)] (0.50 g, $0.82 \mathrm{mmol})$ in chloroform $(20 \mathrm{~mL})$, and the mixture was stirred vigorously for 2 days. The phases were separated, and a red solid was obtained after evaporation of chloroform and dried under vacuum.

Yield: $0.51 \mathrm{~g}(80 \%), \mathrm{mp} 228-230{ }^{\circ} \mathrm{C}$. ${ }^{1} \mathrm{H}$ NMR in $d_{4}-\mathrm{MeOH}$ : $\delta 1.32\left[\mathrm{~d}, 12 \mathrm{H},\left(\mathrm{CH}_{3}\right)_{2} \mathrm{CH},{ }^{3} \mathrm{~J}=6.8 \mathrm{~Hz}\right.$ ], $2.25\left[\mathrm{~s}, 6 \mathrm{H}, \mathrm{CH}_{3}\right]$, 2.80-2.89 [m, 2H, $\left.\mathrm{CH}\left(\mathrm{CH}_{3}\right)_{2}\right], 5.66\left[\mathrm{~d}, 4 \mathrm{H}, \mathrm{CH}_{\mathrm{arom}},{ }^{3} \mathrm{~J}=6.3\right.$ $\mathrm{Hz}$ ], 5.88 [d, $\left.4 \mathrm{H}, \mathrm{CH}_{\mathrm{arom}},{ }^{3} \mathrm{~J}=6.3 \mathrm{~Hz}\right] .{ }^{13} \mathrm{C} \mathrm{NMR}$ in $d_{4}-\mathrm{MeOH}$ : $\delta 18.4\left[\mathrm{CH}_{3}\right], 21.4\left[\left(\mathrm{CH}_{3}\right)_{2} \mathrm{CH}\right], 31.7\left[\mathrm{CH}\left(\mathrm{CH}_{3}\right)_{2}\right], 78.8[\mathrm{CH}], 79.1$ $[\mathrm{CH}], 90.1\left[\mathrm{C}_{\text {arom }}\right], \overline{102.6}\left[\mathrm{C}_{\text {arom }}\right]$.

$\operatorname{Bis}\left[\right.$ diiodido $\left(\eta^{6}\right.$-p-cymene)ruthenium(II)], $\mathbf{1}^{\prime \prime}$. A solution of potassium iodide $(3.25 \mathrm{~g}, 19.6 \mathrm{mmol})$ in water $(20 \mathrm{~mL})$ was added to a solution of $\operatorname{bis}\left[\operatorname{dichlorido}\left(\eta^{6}-p\right.\right.$-isopropyltoluol)ruthenium(II)] $(0.60 \mathrm{~g}, 0.98 \mathrm{mmol})$ in chloroform $(20 \mathrm{~mL})$, and the mixture was stirred vigorously for 2 days. The phases were separated, and a dark violet solid was obtained after evaporation of chloroform and dried under vacuum.

Yield: $0.87 \mathrm{~g}(91 \%), \mathrm{mp} 240-245^{\circ} \mathrm{C} .{ }^{1} \mathrm{H}$ NMR in $d_{4}-\mathrm{MeOH}$ : $\delta 1.31\left[\mathrm{~d}, 12 \mathrm{H},\left(\mathrm{CH}_{3}\right)_{2} \mathrm{CH},{ }^{3} \mathrm{~J}=6.8 \mathrm{~Hz}\right], 2.35\left[\mathrm{~s}, 6 \mathrm{H}, \mathrm{CH}_{3}\right]$, 2.85-2.92 [m, 2H, $\left.\overline{\mathrm{C}} \mathrm{H}\left(\mathrm{CH}_{3}\right)_{2}\right], 5.64\left[\mathrm{~d}, 4 \mathrm{H}, \mathrm{CH}_{\text {arom }},{ }^{3} \mathrm{~J}=6.1\right.$ $\mathrm{Hz}$, $5.86\left[\mathrm{~d}, 4 \mathrm{H}, \mathrm{CH}_{\text {arom }},{ }^{3} \mathrm{~J}=6.1 \mathrm{~Hz}\right] .{ }^{13} \mathrm{C} \mathrm{NMR}$ in $d_{4}-\mathrm{MeOH}$ : $\delta 19.4\left[\mathrm{CH}_{3}\right], 21.8\left[\left(\mathrm{CH}_{3}\right)_{2} \mathrm{CH}\right], 32.1\left[\mathrm{CH}\left(\mathrm{CH}_{3}\right)_{2}\right], 79.3[\mathrm{CH}], 80.1$ $[\mathrm{CH}], 90.1\left[\mathrm{C}_{\text {arom }}\right], \overline{10} 2.4\left[\mathrm{C}_{\text {arom }}\right]$.

2,2', 2' -Tris[3-benzyloxy-2-methyl-4(1H)-pyridinon-1-yl]triethylamine (6a). Sodium hydroxide $(1.40 \mathrm{~g}, 35.0 \mathrm{mmol})$ was added to a solution of 3-benzyloxy-2-methyl-4-pyrone ( $10.0 \mathrm{~g}, 46.2 \mathrm{mmol})$ and tris(2-aminoethyl)amine $(1.5 \mathrm{~g}, 10.3 \mathrm{mmol})$ in a methanol/water mixture $(2: 1,210 \mathrm{~mL})$. The reaction mixture was refluxed for $48 \mathrm{~h}$ and then allowed to cool to room temperature. The product was extracted with dichloromethane $(3 \times 50 \mathrm{~mL})$, and the solvents were removed under vacuum, yielding a brown oil. The beige product was obtained by silica gel chromatography with pure methanol.

Yield: $3.05 \mathrm{~g}(40 \%), \mathrm{mp} 199-200{ }^{\circ} \mathrm{C}$. MS (ESI $\left.{ }^{+}\right): m / z 742$ $[\mathrm{M}+\mathrm{H}]^{+} .{ }^{1} \mathrm{H} \mathrm{NMR}$ in $d_{4}-\mathrm{MeOH}: \delta 2.20\left[\mathrm{~s}, 9 \mathrm{H}, \mathrm{CH}_{3}\right], 2.76$ $\left[\mathrm{t}, 6 \mathrm{H}, \mathrm{CH}_{2} \mathrm{CH}_{2}-\mathrm{N},{ }^{3} \mathrm{~J}=6.8 \mathrm{~Hz}\right], 3.81\left[\mathrm{t}, 6 \mathrm{H}, \mathrm{CH}_{2}-\mathrm{N},{ }^{3} \mathrm{~J}=\right.$ $6.8 \mathrm{~Hz}$ ] $, 5.13\left[\mathrm{~s}, 6 \mathrm{H}, \mathrm{CH}_{2}-\mathrm{Ph}\right], 6.46\left[\mathrm{~d}, 3 \mathrm{H}, \mathrm{CH}-\overline{\mathrm{C}}=\mathrm{O},{ }^{3} \mathrm{~J}=\right.$ $7.0 \mathrm{~Hz}], 7.25-7.42\left[\mathrm{~m}, 15 \mathrm{H}, \mathrm{CH}_{\text {arom }}\right], 7.49\left[\mathrm{~d}, 3 \mathrm{H}, \mathrm{CH},{ }^{3} \mathrm{~J}=7.5\right.$ $\mathrm{Hz}$ ]. ${ }^{13} \mathrm{C}$ NMR in $d_{4}-\mathrm{MeOH}: \delta 12.0\left[\mathrm{CH}_{3}\right], 52.0\left[\mathrm{CH}_{2} \mathrm{CH}_{2}-\mathrm{N}\right]$, $54.2\left[\mathrm{CH}_{2}-\mathrm{N}\right], 73.3\left[\mathrm{CH}_{2}-\mathrm{Ph}\right], 116.3[\mathrm{CH}-\mathrm{C}=\mathrm{O}], 128.4[\mathrm{CH}]$, $128.4[\mathrm{CH}], 129.3[\mathrm{CH}], 137.5\left[\mathrm{C}_{\text {arom }}\right], 140.6[\mathrm{CH}], 143.5[\mathrm{C}-$ $\mathrm{CH}_{3}$ ], 146.1 [C-O], 173.9 [C=O].

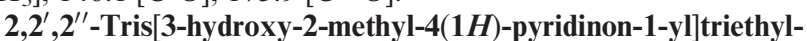
amine (6b). Hydrogen was passed through a suspension of $6 \mathbf{6}(0.50 \mathrm{~g}$, $0.67 \mathrm{mmol})$ and palladium on activated carbon $(0.10 \mathrm{~g})$ in $100 \%$ acetic acid $(40 \mathrm{~mL})$. The conversion was monitored by means of TLC, and the reaction was terminated as soon as the spot of the starting compound had disappeared. The catalyst was filtered off, the solvent was removed, and the product was dried under vacuum.

Yield: $0.20 \mathrm{~g}(63 \%), \mathrm{mp} 200-210{ }^{\circ} \mathrm{C}(\mathrm{dec}) . \mathrm{MS}\left(\mathrm{ESI}^{+}\right): \mathrm{m} / z$ $471[\mathrm{M}+\mathrm{H}]^{+} .{ }^{1} \mathrm{H}$ NMR in $d_{6}$-DMSO: $\delta 2.27\left[\mathrm{~s}, 9 \mathrm{H}, \mathrm{CH}_{3}\right], 2.79$ $\left[\mathrm{t}, 6 \mathrm{H}, \mathrm{CH}_{2} \mathrm{CH}_{2}-\mathrm{N},{ }^{3} \mathrm{~J}=6.6 \mathrm{~Hz}\right], 3.85\left[\mathrm{t}, 6 \mathrm{H}, \mathrm{CH}_{2}-\mathrm{N},{ }^{3} \mathrm{~J}=\right.$ $6.6 \mathrm{~Hz}], 6.09\left[\mathrm{~d}, 3 \mathrm{H}, \mathrm{CH}-\mathrm{C}=\mathrm{O},{ }^{3} \mathrm{~J}=7.3 \mathrm{~Hz}\right], 7.37$ [d, 3H, CH, $\left.{ }^{3} J=7.3 \mathrm{~Hz}\right] \cdot{ }^{13} \mathrm{C}$ NMR in $d_{6}$-DMSO: $\delta 12.3\left[\mathrm{CH}_{3}\right], 51.5$ $\left[\mathrm{CH}_{2} \mathrm{CH}_{2}-\mathrm{N}\right], 54.6\left[\mathrm{CH}_{2}-\mathrm{N}\right], 111.3[\mathrm{CH}-\mathrm{C}=\mathrm{O}], 129.2\left[\mathrm{C}-\mathrm{CH}_{3}\right]$, $139.0[\mathrm{CH}], 146.3[\mathrm{C}-\mathrm{O}], 169.8[\mathrm{C}=\mathrm{O}]$.

General Procedure for the Synthesis of the Complexes. A solution of bis[dichlorido $\left(\eta^{6}-p\right.$-cymene)metal(II)] (metal $=$ osmium, ruthenium) in methanol was added to a suspension of pyridinone ligand and sodium methoxide in methanol. The reaction mixture was stirred at room temperature for 2-4 days. The excess of ligand was removed by filtration, and the solvent was evaporated under vacuum.

1,6-Bis $\{$ chlorido[3-(oxo- $\kappa O)$-2-methyl-4-(1H)-pyridinonato- $\kappa O 4]$ $\left(\boldsymbol{\eta}^{6}\right.$-p-cymene)osmium(II) $\}$ hexane (1a). Bis[dichlorido $\left(\eta^{6}-p\right.$ cymene)osmium(II)] (202 mg, $0.26 \mathrm{mmol})$ in methanol $(30 \mathrm{~mL})$, 
1,6-bis[3-hydroxy-2-methyl-4(1H)-pyridinon-1-yl]hexane (100 mg, $0.30 \mathrm{mmol})$, and sodium methoxide $(36 \mathrm{mg}, 0.66 \mathrm{mmol})$ in methanol $(30 \mathrm{~mL})$ were used. The complex was extracted with a dichloromethane/diethyl ether mixture $(2: 1,45 \mathrm{~mL})$, the solvent was removed, and the yellow compound was dried under vacuum.

Yield: $176 \mathrm{mg}(66 \%), \mathrm{mp} 248-254{ }^{\circ} \mathrm{C}$ (dec). $\mathrm{MS}\left(\mathrm{ESI}^{+}\right): \mathrm{m} / z$ $490[\mathrm{M}-2 \mathrm{Cl}]^{2+} .{ }^{1} \mathrm{H}$ NMR in $d_{4}-\mathrm{MeOH}: \delta 1.29-1.32[\mathrm{~m}, 16 \mathrm{H}$, $\mathrm{CH}_{2}\left(\mathrm{CH}_{2}\right)_{2}-\mathrm{N},\left(\mathrm{CH}_{3}\right)_{2} \mathrm{CH}$ ], 1.74 [brs, $4 \mathrm{H}, \mathrm{CH}_{2} \mathrm{CH}_{2}-\mathrm{N}$ ], $2.31[\mathrm{~s}$, $\left.6 \overline{\mathrm{H}}, \mathrm{CH}_{3}\right], 2.48\left[\mathrm{~s}, \overline{6 \mathrm{H}}, \mathrm{CH}_{3}\right], 2.64-2.73\left[\mathrm{~m}, 2 \overline{\mathrm{H}}, \mathrm{CH}\left(\mathrm{CH}_{3}\right)_{2}\right], 4.09$ $\left[\mathrm{t}, 4 \mathrm{H}, \mathrm{CH}_{2}-\mathrm{N},{ }^{3} \mathrm{~J}=7.5 \mathrm{~Hz}\right], 5.87\left[\mathrm{~d}, 4 \mathrm{H}, \mathrm{CH}_{\text {arom, }}{ }^{3} \mathrm{~J}=5.6 \mathrm{~Hz}\right]$, $6.10\left[\mathrm{~d}, 4 \mathrm{H}, \mathrm{CH}_{\text {arom }},{ }^{3} \mathrm{~J}=5.6 \mathrm{~Hz}\right], 6.55\left[\mathrm{~d}, 2 \mathrm{H}, \mathrm{CH}-\mathrm{C}=\mathrm{O},{ }^{3} \mathrm{~J}=\right.$ $6.8 \mathrm{~Hz}], 7.44\left[\mathrm{~d}, 2 \mathrm{H}, \mathrm{CH},{ }^{3} \mathrm{~J}=6.8 \mathrm{~Hz}\right] .{ }^{13} \mathrm{C} \mathrm{NMR}$ in $d_{4}-\mathrm{MeOH}$ : $\delta 10.9\left[\mathrm{CH}_{3}\right], 18.0\left[\mathrm{CH}_{3}\right], 22.0\left[\left(\mathrm{CH}_{3}\right)_{2} \mathrm{CH}\right], 25.8\left[\mathrm{CH}_{2}\left(\mathrm{CH}_{2}\right)_{2}-\mathrm{N}\right]$, $30.4\left[\mathrm{CH}_{2} \mathrm{CH}_{2} \mathrm{~N}\right], 32.1\left[\mathrm{CH}\left(\mathrm{CH}_{3}\right)_{2}\right], 54.8\left[\mathrm{CH}_{2}-\mathrm{N}\right], 68.1[\mathrm{CH}]$, $70.5[\overline{\mathrm{C}} \mathrm{H}], 85.8\left[\mathrm{C}_{\text {arom }}\right], \overline{8} 6.6\left[\mathrm{C}_{\text {arom }}\right], 109.0[\mathrm{CH}-\mathrm{C}=\mathrm{O}], 134.2$ $[\mathrm{CH}], 134.3\left[\mathrm{C}-\mathrm{CH}_{3}\right], 167.7[\mathrm{C}-\mathrm{O}], 175.7[\mathrm{C}=\mathrm{O}]$.

1,8-Bis chlorido[3-(oxo- $\mathrm{KO})$-2-methyl-4- $(1 \mathrm{H})$-pyridinonato- $\mathrm{K} O 4]$ $\left(\boldsymbol{\eta}^{6}\right.$-p-cymene)osmium(II) $\}$ octane (2a). Bis[dichlorido $\left(\eta^{6}-p\right.$ cymene)osmium(II)] (199 mg, $0.25 \mathrm{mmol})$ in methanol $(20 \mathrm{~mL})$, 1,8-bis[3-hydroxy-2-methyl-4(1H)-pyridinon-1-yl]octane (130 mg, $0.36 \mathrm{mmol}$ ), and sodium methoxide (43 $\mathrm{mg}, 0.79 \mathrm{mmol})$ in methanol $(20 \mathrm{~mL})$ were used. The complex was extracted with a dichloromethane/diethyl ether mixture $(2: 1,60 \mathrm{~mL})$, and the solvent was removed. The compound was dissolved in dichloromethane, and a yellow precipitate was obtained by addition of $n$-hexane, which was filtered off and dried under vacuum.

Yield: $82 \mathrm{mg}(30 \%), \mathrm{mp} 248-250{ }^{\circ} \mathrm{C}(\mathrm{dec}) . \mathrm{MS}\left(\mathrm{ESI}^{+}\right): \mathrm{m} / z$ $504[\mathrm{M}-2 \mathrm{Cl}]^{2+} .{ }^{1} \mathrm{H}$ NMR in $d_{4}-\mathrm{MeOH}: \delta 1.30-1.32[\mathrm{~m}, 20 \mathrm{H}$, $\left.\mathrm{CH}_{2}\left(\mathrm{CH}_{2}\right)_{3}-\mathrm{N}, \mathrm{CH}_{2}\left(\mathrm{CH}_{2}\right)_{2}-\mathrm{N},\left(\mathrm{CH}_{3}\right)_{2} \mathrm{CH}\right], 1.73-1.76[\mathrm{~m}, 4 \mathrm{H}$, $\left.\mathrm{C}_{2} \mathrm{CH}_{2}-\mathrm{N}\right], 2.32\left[\mathrm{~s}, 6 \mathrm{H}, \mathrm{CH}_{3}\right], 2 . \overline{49}\left[\mathrm{~s}, 6 \mathrm{H}, \mathrm{CH}_{3}\right], 2.67-2.74[\mathrm{~m}$, $2 \overline{\mathrm{H}}, \mathrm{CH}\left(\mathrm{CH}_{3}\right)_{2}$ ], $4.11\left[\mathrm{t}, 4 \mathrm{H}, \mathrm{CH}_{2}-\mathrm{N},{ }^{3} \mathrm{~J}=7.8 \mathrm{~Hz}\right.$ ], $5.90[\mathrm{~d}, 4 \mathrm{H}$, $\left.\mathrm{CH}_{\text {arom }},{ }^{3} \mathrm{~J}=5.6 \mathrm{~Hz}\right], 6.12\left[\mathrm{~d}, \overline{4 \mathrm{H}}, \mathrm{CH}_{\text {arom }},{ }^{3} \mathrm{~J}=5.3 \mathrm{~Hz}\right], 6.58[\mathrm{~d}$, $\left.2 \mathrm{H}, \mathrm{CH}-\mathrm{C}=\mathrm{O},{ }^{3} \mathrm{~J}=6.8 \mathrm{~Hz}\right], 7.47\left[\mathrm{~d}, 2 \mathrm{H}, \mathrm{CH},{ }^{3} \mathrm{~J}=6.8 \mathrm{~Hz}\right] .{ }^{13} \mathrm{C}$ NMR in $d_{4}-\mathrm{MeOH}: \delta 10.9\left[\mathrm{CH}_{3}\right], 18.1\left[\mathrm{CH}_{3}\right], 22.1\left[\left(\mathrm{CH}_{3}\right)_{2} \mathrm{CH}\right]$, $26.1\left[\mathrm{CH}_{2}\left(\mathrm{CH}_{2}\right)_{3}-\mathrm{N}\right], 28.9\left[\mathrm{CH}_{2}\left(\mathrm{CH}_{2}\right)_{2}-\mathrm{N}\right], 30.6\left[\mathrm{C}_{2} \mathrm{CH}_{2}-\mathrm{N}\right]$, $32.1\left[\overline{\mathrm{CH}}\left(\mathrm{CH}_{3}\right)_{2}\right], 55.0\left[\mathrm{CH}_{2}-\mathrm{N}\right], 68.2[\mathrm{CH}], 70 . \overline{6}[\mathrm{CH}], 84.9$ $\left[\mathrm{C}_{\text {arom }}\right], 86.5\left[\mathrm{C}_{\text {arom }}\right], 108.9[\mathrm{CH}-\mathrm{C}=\mathrm{O}], 134.2[\mathrm{CH}], 134.3[\mathrm{C}-$ $\left.\mathrm{CH}_{3}\right], 161.8[\mathrm{C}-\mathrm{O}], 175.7[\mathrm{C}=\mathrm{O}]$.

1,6-Bis $\{$ bromido[3-(oxo- $\kappa O)$-2-methyl-4-(1H)-pyridinonato- $\kappa O 4]$ $\left(\boldsymbol{\eta}^{6}\right.$-p-cymene)ruthenium(II) $\}$ hexane (3a). Bis[dibromido $\left(\eta^{6}-p\right.$ cymene)ruthenium(II)] (184 mg, $0.23 \mathrm{mmol})$ in methanol $(20 \mathrm{~mL})$, 1,6-bis[3-hydroxy-2-methyl-4(1H)-pyridinon-1-yl]hexane (103 mg, $0.31 \mathrm{mmol})$, and sodium methoxide $(37 \mathrm{mg}, 0.68 \mathrm{mmol})$ in methanol $(20 \mathrm{~mL})$ were used. The complex was extracted with a dichloromethane/diethyl ether mixture $(2: 1,45 \mathrm{~mL})$, and the solvent was removed. The compound was dissolved in dichloromethane, precipitated by addition of $n$-hexane, filtered off, and dried under vacuum.

Yield: $85 \mathrm{mg}(38 \%), \mathrm{mp} 130-135{ }^{\circ} \mathrm{C} . \mathrm{MS}\left(\mathrm{ESI}^{+}\right): m / z 401$ $[\mathrm{M}-2 \mathrm{Br}]^{2+} .{ }^{1} \mathrm{H}$ NMR in $d_{4}-\mathrm{MeOH}: \delta 1.31-1.34[\mathrm{~m}, 16 \mathrm{H}$, $\mathrm{CH}_{2}\left(\mathrm{CH}_{2}\right)_{2}-\mathrm{N},\left(\mathrm{CH}_{3}\right)_{2} \mathrm{CH}$ ], 1.70 [brs, $4 \mathrm{H}, \mathrm{CH}_{2} \mathrm{CH}_{2}-\mathrm{N}$ ], 2.29 $\left[\mathrm{s}, 6 \mathrm{H}, \mathrm{CH}_{3}\right], 2.46\left[\mathrm{~s}, 6 \mathrm{H}, \mathrm{CH}_{3}\right], 2.82-2.90\left[\mathrm{~m}, \overline{2} \mathrm{H}, \mathrm{CH}\left(\mathrm{CH}_{3}\right)_{2}\right]$, $4.04\left[\mathrm{t}, 4 \mathrm{H}, \mathrm{CH}_{2}-\mathrm{N},{ }^{3} \mathrm{~J}=7.5 \mathrm{~Hz}\right.$ ], $5.43\left[\mathrm{~d}, 4 \mathrm{H}, \mathrm{CH}_{\text {arom }}{ }^{3} \mathrm{~J}=5.8\right.$ $\mathrm{Hz}$ ], 5.64 [d, 4H, $\mathrm{CH}_{\text {arom }}{ }^{3} \mathrm{~J}=5.8 \mathrm{~Hz}$ ], 6.48 [d, $2 \mathrm{H}, \mathrm{CH}-\mathrm{C}=\mathrm{O}$, ${ }^{3} J=6.8 \mathrm{~Hz}$, $7.38\left[\mathrm{~d}, 2 \mathrm{H}, \mathrm{CH},{ }^{3} \mathrm{~J}=6.8 \mathrm{~Hz}\right]{ }^{13} \mathrm{C} \mathrm{NMR}$ in $d_{4^{-}}$ $\mathrm{MeOH}: \delta 10.8\left[\mathrm{CH}_{3}\right], 17.7\left[\mathrm{CH}_{3}\right], 21.6\left[\left(\mathrm{CH}_{3}\right)_{2} \mathrm{CH}\right], 25.8$ $\left[\mathrm{CH}_{2}\left(\mathrm{CH}_{2}\right)_{2} \mathrm{-N}\right], 30.4\left[\mathrm{CH}_{2} \mathrm{CH}_{2} \mathrm{~N}\right], 31.4\left[\mathrm{CH}\left(\mathrm{CH}_{3}\right)_{2}\right], 54.8$ $\left[\overline{\mathrm{C}} \mathrm{H}_{2}-\mathrm{N}\right], 78.1[\mathrm{CH}], 79.5[\mathrm{CH}], 95.8\left[\mathrm{C}_{\text {arom }}\right], 99.1\left[\mathrm{C}_{\text {arom }}\right]$, $109.3[\mathrm{CH}-\mathrm{C}=\mathrm{O}], 133.6[\mathrm{CH}], 134.1\left[\mathrm{C}-\mathrm{CH}_{3}\right], 162.5[\mathrm{C}-\mathrm{O}]$, $174.1[\mathrm{C}=\mathrm{O}]$.

1,6-Bis $\{$ iodido[3-(oxo- $\kappa O)$-2-methyl-4-(1H)-pyridinonato- $\kappa O 4]$ $\left(\eta^{6}\right.$-p-cymene)ruthenium(II) $\}$ hexane $(\mathbf{3 b})$. $\operatorname{Bis}\left[\operatorname{diiodido}\left(\eta^{6}-p\right.\right.$ cymene)ruthenium(II)] (309 $\mathrm{mg}, 0.32 \mathrm{mmol})$ in methanol $(25 \mathrm{~mL})$, 1,6-bis[3-hydroxy-2-methyl-4(1H)-pyridinon-1-yl]hexane (150 mg, $0.45 \mathrm{mmol}$ ), and sodium methoxide $(54 \mathrm{mg}, 0.99 \mathrm{mmol})$ in methanol $(25 \mathrm{~mL})$ were used. The complex was extracted with a dichloromethane/diethyl ether mixture $(2: 1,65 \mathrm{~mL})$, and the solvent was removed. The compound was dissolved in dichloromethane, precipitated by addition of $n$-hexane, filtered off, and dried under vacuum.
Yield: $255 \mathrm{mg}(77 \%), \mathrm{mp} 128-130{ }^{\circ} \mathrm{C} . \mathrm{MS}\left(\mathrm{ESI}^{+}\right): \mathrm{m} / z 401$ $[\mathrm{M}-2 \mathrm{I}]^{2+} .{ }^{1} \mathrm{H}$ NMR in $d_{4}-\mathrm{MeOH}: \delta 1.32-1.34[\mathrm{~m}, 16 \mathrm{H}$, $\left.\mathrm{CH}_{2}\left(\mathrm{CH}_{2}\right)_{2}-\mathrm{N},\left(\mathrm{CH}_{3}\right)_{2} \mathrm{CH}\right], 1.70$ [brs, $4 \mathrm{H}, \mathrm{CH}_{2} \mathrm{CH}_{2}-\mathrm{N}$ ], 2.32 [s, $\left.6 \overline{\mathrm{H}}, \mathrm{CH}_{3}\right], 2.43\left[\mathrm{~s}, \overline{6 \mathrm{H}}, \mathrm{CH}_{3}\right], 2.88-2.95\left[\mathrm{~m}, 2 \overline{\mathrm{H}}, \mathrm{CH}\left(\mathrm{CH}_{3}\right)_{2}\right], 4.04$ [t, $4 \mathrm{H}, \mathrm{CH}_{2}-\mathrm{N},{ }^{3} \mathrm{~J}=6.8 \mathrm{~Hz}$ ], $5.42\left[\mathrm{~d}, 4 \mathrm{H}, \mathrm{CH}_{\text {arom }}{ }^{3} \mathrm{~J}=6.1 \mathrm{~Hz}\right.$, $5.62\left[\mathrm{~d}, 4 \mathrm{H}, \mathrm{CH}_{\text {arom }}{ }^{3} \mathrm{~J}=6.1 \mathrm{~Hz}\right], 6.44\left[\mathrm{~d}, 2 \mathrm{H}, \mathrm{CH}-\mathrm{C}=\mathrm{O},{ }^{3} \mathrm{~J}=\right.$ $6.8 \mathrm{~Hz}], 7.40\left[\mathrm{~d}, 2 \mathrm{H}, \mathrm{CH},{ }^{3} \mathrm{~J}=6.8 \mathrm{~Hz}\right] .{ }^{13} \mathrm{C} \mathrm{NMR}$ in $d_{4}-\mathrm{MeOH}$ : $\delta 10.9\left[\mathrm{CH}_{3}\right], 18.3\left[\mathrm{CH}_{3}\right], 21.8\left[\left(\mathrm{CH}_{3}\right)_{2} \mathrm{CH}\right], 25.7\left[\mathrm{CH}_{2}\left(\mathrm{CH}_{2}\right)_{2}-\mathrm{N}\right]$, $30.4\left[\mathrm{CH}_{2} \mathrm{CH}_{2} \mathrm{~N}\right], 31.6\left[\mathrm{CH}\left(\mathrm{CH}_{3}\right)_{2}\right], 54.7\left[\mathrm{CH}_{2}-\mathrm{N}\right], 78.7[\mathrm{CH}]$, $79.6[\overline{\mathrm{C}} \mathrm{H}], 84.9\left[\mathrm{C}_{\text {arom }}\right], \overline{9} 5.3\left[\mathrm{C}_{\text {arom }}\right], 109.2[\mathrm{CH}-\mathrm{C}=\mathrm{O}], 133.5$ $[\mathrm{CH}], 133.9\left[\mathrm{C}-\mathrm{CH}_{3}\right], 167.7[\mathrm{C}-\mathrm{O}], 188.4[\mathrm{C}=\mathrm{O}]$.

1,6-Bis $\{$ chlorido[3-(oxo- $\kappa O)$-2-methyl-4-(1H)-pyridinonato- $\kappa O 4]$ ( $\boldsymbol{\eta}^{6}$-biphenyl)ruthenium(II) $\}$ hexane (4). Bis[dichlorido $\left(\eta^{6}\right.$ biphenyl)ruthenium(II)] (147 mg, $0.23 \mathrm{mmol}$ ) in dichloromethane (25 mL), 1,6-bis[3-hydroxy-2-methyl-4(1H)-pyridinon-1-yl]hexane ( $100 \mathrm{mg}, 0.30 \mathrm{mmol})$, and sodium methoxide $(36 \mathrm{mg}, 0.66 \mathrm{mmol})$ in dichloromethane $(25 \mathrm{~mL})$ were used. The complex was extracted with a dichloromethane/diethyl ether mixture $(2: 1,65 \mathrm{~mL})$, and the solvent was removed. The compound was dissolved in dichloromethane, precipitated by addition of $n$-hexane, filtered off, and dried under vacuum.

Yield: $95 \mathrm{mg}(46 \%), \mathrm{mp} 188-190{ }^{\circ} \mathrm{C}$. MS $\left(\mathrm{ESI}^{+}\right): m / z 421$ $[\mathrm{M}-2 \mathrm{Cl}]^{2+}$. ${ }^{\mathrm{H}} \mathrm{H}$ NMR in $d_{4}-\mathrm{MeOH}: \delta 1.30\left[\mathrm{brs}, 4 \mathrm{H}, \mathrm{CH}_{2}\right.$ $\left(\mathrm{CH}_{2}\right)_{2}-\mathrm{N}$ ], 1.67 [brs, 4H, $\mathrm{CH}_{2} \mathrm{CH}_{2}-\mathrm{N}$ ], 2.40 [s, 6H, $\mathrm{CH}_{3}$ ], 4.03 [t, $\left.4 \mathrm{H}, \mathrm{CH}_{2}-\mathrm{N},{ }^{3} \mathrm{~J}=7.5 \mathrm{~Hz}\right], 5.91-5.94\left[\mathrm{~m}, 6 \mathrm{H}, \mathrm{CH}_{\text {arom }}\right], 6.10$ $\left[\mathrm{d}, 4 \mathrm{H}, \mathrm{CH}_{\text {arom }},{ }^{3} \mathrm{~J}=5.6 \mathrm{~Hz}\right], 6.46\left[\mathrm{~d}, 2 \mathrm{H}, \mathrm{CH}-\mathrm{C}=\mathrm{O},{ }^{3} \mathrm{~J}=6.8\right.$ $\mathrm{Hz}$, $7.37\left[\mathrm{~d}, 2 \mathrm{H}, \mathrm{CH},{ }^{3} \mathrm{~J}=6.8 \mathrm{~Hz}\right], 7.46-7.48\left[\mathrm{~m}, 6 \mathrm{H}, \mathrm{CH}_{\text {arom }}\right]$, $7.83\left[\mathrm{~m}, 4 \mathrm{H}, \mathrm{CH}_{\text {arom }}\right] .{ }^{13} \mathrm{C} \mathrm{NMR}$ in $d_{4}-\mathrm{MeOH}: \delta 10.8\left[\mathrm{CH}_{3}\right], 25.7$ $\left[\mathrm{CH}_{2}\left(\mathrm{CH}_{2}\right)_{2}-\mathrm{N}\right], 30.4\left[\mathrm{CH}_{2} \mathrm{CH}_{2} \mathrm{~N}\right], 54.7\left[\mathrm{CH}_{2}-\mathrm{N}\right], 78.8[\mathrm{CH}]$, $80.7[\mathrm{CH}], 80.9[\mathrm{CH}], 94.4\left[\mathrm{C}_{\text {arom }}\right], 109.4[\mathrm{CH}-\mathrm{C}=\mathrm{O}], 128.9$ $[\mathrm{CH}], 129.6[\mathrm{CH}], 132.1\left[\mathrm{C}_{\text {arom }}\right], 133.8[\mathrm{CH}], 134.4\left[\mathrm{C}-\mathrm{CH}_{3}\right]$, $159.4[\mathrm{C}-\mathrm{O}], 173.8[\mathrm{C}=\mathrm{O}]$.

2,2',2' -Tris[chlorido[3-(oxo- $\kappa O)$-2-methyl-4(1H)-pyridinonato$\kappa \boldsymbol{O} 4]\left(\boldsymbol{\eta}^{6}\right.$-p-cymene)ruthenium(II)] triethylamine (6c). Bis[dichlorido $\left(\eta^{6}\right.$-p-cymene)ruthenium(II)] (166 mg, $\left.0.27 \mathrm{mmol}\right)$ in methanol $(20 \mathrm{~mL})$, pyridinone $\mathbf{6 b}(100 \mathrm{mg}, 0.21 \mathrm{mmol})$, and sodium methoxide ( $38 \mathrm{mg}, 0.7 \mathrm{mmol})$ in methanol $(20 \mathrm{~mL})$ were used. The complex was extracted with a dichloromethane/diethyl ether mixture $(2: 1,65 \mathrm{~mL})$, and the solvent was removed. The compound was dissolved in dichloromethane, precipitated by addition of $n$-hexane, filtered off, and dried under vacuum.

Yield: $150 \mathrm{mg}(55 \%), \mathrm{mp} 258-260{ }^{\circ} \mathrm{C}$ (dec). $\mathrm{MS}\left(\mathrm{ESI}^{+}\right): \mathrm{m} / z$ $1245[\mathrm{M}-\mathrm{Cl}]^{+}, 604[\mathrm{M}-2 \mathrm{Cl}]^{2+}, 392[\mathrm{M}-3 \mathrm{Cl}]^{3+} .{ }^{1} \mathrm{H} \mathrm{NMR}$ in $d_{4}$-MeOH: $\delta 1.31\left[\mathrm{~d}, 18 \mathrm{H},\left(\mathrm{CH}_{3}\right)_{2} \mathrm{CH},{ }^{3} J=6.8 \mathrm{~Hz}\right], 2.25[\mathrm{~s}, 9 \mathrm{H}$, $\left.\mathrm{CH}_{3}\right], 2.41\left[\mathrm{~s}, 9 \mathrm{H}, \mathrm{CH}_{3}\right], 2.74$ [brs, 6H, $\left.\mathrm{CH}_{2} \mathrm{CH}_{2}-\mathrm{N}\right], 2.80-$ $2.87\left[\mathrm{~m}, 3 \mathrm{H}, \mathrm{CH}\left(\mathrm{CH}_{3}\right)_{2}\right.$, ], 3.78 [brs, $6 \mathrm{H}, \mathrm{CH}_{2}-\mathrm{N}$ ], 5.39 [d, $6 \mathrm{H}$, $\left.\mathrm{CH}_{\text {arom }},{ }^{3} \mathrm{~J}=\overline{4.8} \mathrm{~Hz}\right], 5.62\left[\mathrm{~d}, 6 \mathrm{H}, \mathrm{CH}_{\text {arom }}{ }^{3} \mathrm{~J}=5.0 \mathrm{~Hz}\right], 6.38$ $\left[\mathrm{d}, 3 \mathrm{H}, \mathrm{CH}-\mathrm{C}=\mathrm{O},{ }^{3} \mathrm{~J}=4.3 \mathrm{~Hz}\right], 6.85\left[\mathrm{~d}, 3 \mathrm{H}, \mathrm{CH},{ }^{3} \mathrm{~J}=5.3 \mathrm{~Hz}\right]$. ${ }^{13} \mathrm{C}$ NMR in $d_{4}-\mathrm{MeOH}: \delta 11.1\left[\mathrm{CH}_{3}\right], 17.6\left[\mathrm{CH}_{3}\right], 21.6$ $\left[\left(\mathrm{CH}_{3}\right)_{2} \mathrm{CH}\right], 31.4\left[\mathrm{CH}\left(\mathrm{CH}_{3}\right)_{2}\right], 52.8\left[\mathrm{CH}_{2} \mathrm{CH}_{2}-\mathrm{N}\right], 54.4\left[\mathrm{CH}_{2^{-}}\right.$ $\mathrm{N}], 78.0[\mathrm{CH}], 79.7 \overline{[C H}], 95.9\left[\mathrm{C}_{\text {arom }}\right], 99.1\left[\mathrm{C}_{\text {arom }}\right], 109.3 \overline{[C H}-$ $\mathrm{C}=\mathrm{O}], 133.3\left[\mathrm{C}-\mathrm{CH}_{3}\right], 134.5[\mathrm{CH}], 159.8[\mathrm{C}-\mathrm{O}], 174.5[\mathrm{C}=\mathrm{O}]$.

Aquation. The aquation was studied using UV-vis and ${ }^{1} \mathrm{H}$ NMR spectroscopy. The UV-vis spectra were recorded from 200 to $500 \mathrm{~nm}$ at concentrations of $0.5 \mathrm{mM}$ complex, and the process was followed for $24 \mathrm{~h}$ using a Perkin-Elmer Lambda 650 instrument. For NMR spectroscopy, samples were dissolved in $\mathrm{H}_{2} \mathrm{O} / \mathrm{D}_{2} \mathrm{O}(9: 1)$ at $25^{\circ} \mathrm{C}$, and ${ }^{1} \mathrm{H}$ NMR spectra were recorded.

Experimental Protocol for Cell Culture Studies. Cell Lines and Cell Culture Conditions. Human SW480 (colon adenocarcinoma) and A2780 (ovarian carcinoma) cells were kindly provided by Brigitte Marian (Institute of Cancer Research, Medical University of Vienna, Austria) and Evelyn Dittrich (General Hospital, Medical University of Vienna, Austria), respectively. Cells were grown in $75 \mathrm{~cm}^{2}$ culture flasks (Iwaki/Asahi Technoglass, Gyouda, Japan) as adherent monolayer cultures in complete culture medium, i.e., minimal essential medium (MEM) supplemented with $10 \%$ heat-inactivated fetal bovine serum, $1 \mathrm{mM}$ sodium pyruvate, $4 \mathrm{mM}$ L-glutamine, and $1 \%$ nonessential amino acids $(100 \times)$ (all purchased from Gibco/Invitrogen, Paisley, UK) 
without antibiotics. The cell lines 5637 and RT-4 (bladder cancer), LCLC-103H and A-427 (lung cancer), DAN-G (pancreatic cancer), and MCF-7 (breast cancer) were obtained from the German Collection of Microorganisms and Cell Culture (DSMZ, Braunschweig, FRG). The three oxoplatin-resistant cell lines were established at the University of Greifswald through weekly exposure of cells to increasing concentrations of oxoplatin over a period of several months. These cells were grown in culture flasks (Sarstedt, Germany) as adherent monolayer cultures in $90 \%$ RPMI medium supplemented with $10 \%$ heat-inactivated fetal bovine serum and the antibiotics benzylpenicillin and streptomycin. To the medium for the MCF-7 cells were added $1 \mathrm{mM}$ sodium pyruvate and $1 \%$ nonessential amino acids. All cultures were maintained at $37^{\circ} \mathrm{C}$ in a humidified atmosphere containing $5 \% \mathrm{CO}_{2}$.

MTT Assay Conditions. Cytotoxicity was determined by means of a colorimetric microculture assay [MTT assay, MTT = 3-(4,5dimethyl-2-thiazolyl)-2,5-diphenyl-2 $H$-tetrazolium bromide]. For this purpose, SW480 and A2780 cells were harvested from culture flasks by trypsinization and seeded into 96-well microculture plates (Iwaki/Asahi Technoglass, Gyouda, Japan) in densities of $2.5 \times 10^{3}$ and $5.0 \times 10^{3}$ cells/well, respectively, in order to ensure exponential growth throughout drug exposure. Cells were allowed to settle in drug-free complete culture medium for $24 \mathrm{~h}$, followed by the addition of dilutions of the test compounds in $100 \mu \mathrm{L} /$ well complete culture medium and incubation for $96 \mathrm{~h}$. Compounds with low water solubility were stored in DMSO stock solutions, which were diluted with medium such that the effective DMSO content did not exceed $1 \%$. At the end of exposure, drug solutions were replaced by $100 \mu \mathrm{L} /$ well RPMI 1640 culture medium (supplemented with 10\% heat-inactivated fetal bovine serum and $2 \mathrm{mM}$ L-glutamine) and $20 \mu \mathrm{L} /$ well MTT solution in phosphate-buffered saline $(5 \mathrm{mg} / \mathrm{mL})$. After incubation for $4 \mathrm{~h}$, the medium/MTT mixtures were removed, and the formazan crystals formed by vital cells were dissolved in $150 \mu \mathrm{L}$ of DMSO per well. Optical densities at $550 \mathrm{~nm}$ were measured with a microplate reader (Tecan Spectra Classic) using a reference wavelength of $690 \mathrm{~nm}$ to correct for unspecific absorption. Quantities of vital cells were expressed in terms of $\mathrm{T} / \mathrm{C}$ values by comparison to untreated

(47) Bracht, K.; Boubakari; Grünert, R.; Bednarski, P. J. AntiCancer Drugs 2006, 17, 41-51. controls, and $50 \%$ inhibitory concentrations $\left(\mathrm{IC}_{50}\right)$ were calculated from concentration-effect curves by interpolation. Evaluation is based on means from at least three independent experiments, each comprising six replicates per concentration level.

Crystal Violet Assay Conditions. This assay has been described in detail elsewhere. ${ }^{47}$ Culture conditions were the same as used in the MTT assay. Briefly, cells were seeded into 96-well microculture plates (Sarstedt, FRG) in cell densities of $1.0 \times 10^{3}$ cells/ well, except for LCLC-103H, which was seeded at 250 cells/well. After a $24 \mathrm{~h}$ preincubation, cells were treated with the test substance for $96 \mathrm{~h}$. Stock solutions of test substance were prepared to $20 \mathrm{mM}$ in DMF and diluted 1000-fold in RPMI 1640 culture medium containing $10 \%$ fetal calf serum. Substances that showed a $\geq 50 \%$ growth inhibition at $20 \mu \mathrm{M}$ were tested at 5 serial dilutions in 4 wells/concentration to determine the $\mathrm{IC}_{50}$ values as described. ${ }^{47}$ Staining of cells was done for 30 min with a $0.02 \%$ crystal violet solution in water followed by washing out the excess dye. Cell-bound dye was redissolved in $70 \%$ ethanol/water solution, and the optical densities at $\lambda=570 \mathrm{~nm}$ were measured with a microplate reader (Anthos 2010).

Acknowledgment. We thank the University of Vienna, the Hochschuljubiläumsstiftung Vienna (H-1826/2008), the Theodor-Körner-Fonds, the Austrian Council for Research and Technology Development, the FFG-Austrian Research Promotion Agency (Project FA 526003), the FWF-Austrian Science Fund (Schrödinger Fellowship J2613-N19 [C.G.H.]), the EPFL, and COST D39 for financial support. This research was supported by a Marie Curie Intra European Fellowship within the 7th European Community Framework Programme projects 220890-SuRuCo (A.A.N.). We gratefully acknowledge Prof. Markus Galanski for recording the NMR spectra, and Prof. Patrick J. Bednarski and Magdalena Maruszak (University of Greifswald) for contribution to the in vitro activity data.

Supporting Information Available: Elemental analysis data; $\mathrm{UV} /$ vis data on the hydrolysis of 1a. This material is available free of charge via the Internet at http://pubs.acs.org. 